\title{
PENGEMBANGAN PERANGKAT PEMBELAJARAN MATEMATIKA MODEL PROBLEM BASED INSTRUCTION PADA MATA KULIAH KAPITA SELEKTA MATEMATIKA SEKOLAH DASAR
}

\author{
Ririn Widiyasari \\ Universitas Muhammadiyah Jakarta \\ ririn.putri87@gmail.com
}

\begin{abstract}
ABSTRAK
Tujuan penelitian ini adalah: (1) menghasilkan perangkat pembelajaran matematika model PBI yang valid, (2) mendapatkan efektivitas pembelajaran matematika dengan model PBI dan (3) mengetahui apakah perangkat pembelajaranan matematika model PBI praktis. Jenis penelitian ini adalah penelitian pengembangan yang mengacu pada model Plomp yang dimodifikasi. Perangkat pembelajaran yang dikembangkan terdiri dari silabus, Satuan Acara Perkuliahan (SAP), modul pembelajaran, dan worksheet. Kevalidan perangkat pembelajaran ditentukan berdasarkan validasi tim ahli dan teman sejawat, hasil penilaian oleh lima validator diperoleh kriteria valid dengan klasifikasi baik dan sangat baik. Keefektivan pembelajaran didapatkan dengan lembar pengamatan keaktifan mahasiswa, diperoleh hasil keaktifan mahasiswa termasuk kategori aktif. Sedangkan uji kepraktisan perangkat pembelajaran, dari uji lapangan diperoleh hasil pengamatan terhadap proses pembelajaran, angket respon pengajar dan mahasiswa terhadap pemakaian perangkat pembelajaran semuanya menunjukkan hasil yang baik.
\end{abstract}

Kata Kunci: Perangkat Pembelajaran, Problem Based Instruction, Kapita Selekta Matematika Sekolah Dasar.

\section{PENDAHULUAN}

Penggunaan model pembelajaran matematika yang berpusat pada aktivitas pengajar sebagai sumber belajar dengan prosedur penyampaian materi yang monoton, menyebabkan mahasiswa cepat jenuh dan kurang tertarik mengikutinya secara sunguh-sunguh. Hal ini dapat menyebabkan respon dan sikap mahasiswa sangat rendah terhadap mata kuliah yang diajarkan. Rendahnya respon mahasiswa berdampak terhadap hasil belajar mahasiswa. Di samping itu, perangkat pembelajaran yang digunakan oleh pengajar juga belum menggunakan model pembelajaran yang jelas. Untuk menyelesaikan masalah rendahnya kemandirian belajar 
mahasiswa, serta kemampuan menyelesaikan masalah dengan menggunakan konsep yang telah dipahami, salah satu upaya yang dapat dilakukan adalah melalui kesinergian model pembelajaran dengan tujuan pembelajaran, materi pembelajaran, dan kondisi mahasiswa. Salah satu langkah yang ditempuh untuk menyelesaikan masalah dalam penelitian ini adalah dengan menerapkan pembelajaran matematika menggunakan model Problem Based Instruction (PBI).

Menurut Arends (dalam Trianto, 2009: 92), PBI merupakan salah satu model pembelajaran dimana peserta didik mengerjakan permasalahan yang autentik dengan maksud untuk menyusun pengetahuan mereka sendiri, mengembangkan inkuiri dan keterampilan berpikir tingkat lebih tinggi, mengembangkan kemandirian, dan percaya diri. Sedangkan menurut Kennedy (2009:74) dalam proses belajar bersama diharapkan terjadi interaksi dialogis sehingga terjadi proses transformasi konsep secara kolektif.

Hasil penelitian yang dilakukan oleh Rosita (2013) dengan judul Upaya Penerapan Metode Problem Based Instruction (PBI) untuk Meningkatkan Hasil Belajar Siswa diperoleh bahwa hasil belajar siswa meningkat dengan menggunakan metode $P B I$. Jika metode $P B I$ dikembangkan secara berkelanjutan, hasil belajar siswa yang menggambarkan kemampuan "intellegent memory" akan terus meningkat, sehingga di dalam proses pembelajaran guru tidak lagi menekankan siswa pada pembelajaran yang bersifat ordinary memory namun guru harus mengembangkan pembelajaran pada proses "intellegent memory".

Rumusan masalah dalam penelitian ini adalah bagaimanakah pengembangan dan hasil pengembangan perangkat pembelajaran matematika menggunakan model $P B I$ yang valid, apakah perangkat pembelajaran matematika yang dikembangkan menggunakan model $P B I$ efektif, dan apakah perangkat pembelajaran matematika yang dikembangkan menggunakan model $P B I$ praktis.

\section{METODE PENELITIAN}

Penelitian ini merupakan penelitian pengembangan perangkat. Perangkat pembelajaran yang dikembangkan berupa silabus, SAP, modul pembelajaran, dan worksheet. Selain itu juga dikembangkan instrumen penelitian berupa lembar validasi silabus, SAP, modul pembelajaran, dan worksheet, angket kemandirian belajar mahasiswa, angket sikap mahasiswa dan pengamatan keterampilan proses.

Pengembangan perangkat pembelajaran matematika dengan model PBI untuk meningkatkan kemandirian belajar mahasiswa mengacu pada model pengembangan pendidikan umum dari Plomp (dalam Rochmad, 2009) yang dimodifikasi dari lima tahap 
menjadi empat tahap, yaitu tahap investigasi awal; tahap perancangan; tahap realisasi/konstruksi; dan tahap tes, evaluasi, dan revisi.

a. Tahap investigasi awal.

Kegiatannya adalah menghimpun informasi permasalahan pembelajaran matematika terdahulu dan merumuskan rasional pemikiran pentingnya mengembangkan model pembelajaran, mengidentifikasi dan mengkaji teori-teori yang melandasi pengembangan model pembelajaran.

b. Tahap perancangan

Perangkat pembelajaran yang akan dirancang meliputi silabus; SAP; modul pembelajaran; dan worksheet. Selain itu juga akan dirancang lembar validasi, lembar angket kemandirian belajar, angket sikap mahasiswa terhadap pembelajaran, dan lembar observasi keterampilan proses.

c. Tahap Realisasi /Konstruksi

Kegiatannya adalah menyusun silabus; SAP; modul pembelajaran; dan Worksheet. Perangkat pembelajaran yang telah disusun pada tahap ini disebut dengan draf 1 .

d. Tahap Tes, Evaluasi, dan Revisi

Pada tahap ini dilakukan dua kegiatan utama, yaitu (a) kegiatan validasi yaitu berupa kegiatan validasi draf 1 , analisis hasil validasi, dan revisi ; (b) kegiatan uji coba lapangan draf perangkat pembelajaran yang telah divalidasi.

Alur pengembangan perangkat pembelajaran, dan instrumen dalam penelitian ini seperti digambarkan pada Gambar 1 berikut: 


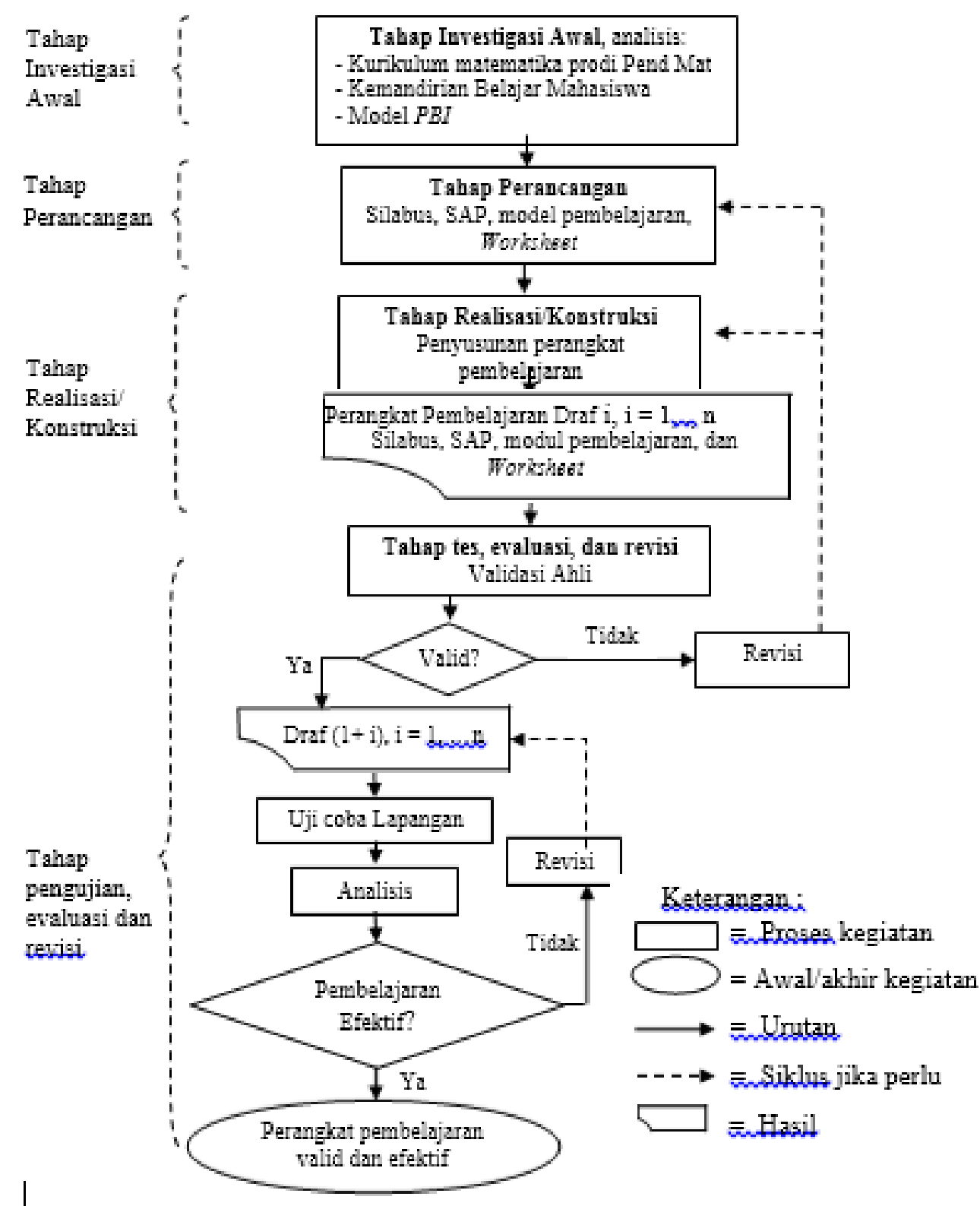

Gambar 1. Skema Alur Pengembangan Perangkat Pembelajaran Matematika

Instrumen penelitian yang digunakan untuk mengumpulkan data terdiri dari angket Kemandirian Belajar Mahasiswa, lembar pengamatan keterampilan proses mahasiswa, angket sikap mahasiswa terhadap matematika, dan lembar validasi. 
Data yang telah terkumpul selanjutnya dianalisis untuk menjawab rumusan masalah atau hipotesis penelitian. Data diperoleh dari para validator dan dari hasil uji coba.

a. Analisis Data Hasil Validasi Ahli

Data yang diperoleh dari hasil validasi, selanjutnya dianalisis secara deskriptif untuk merevisi perangkat pembelajaran. Untuk menganalisis hasil validasi menggunakan analisis rata-rata, yaitu menghitung rata-rata dari setiap aspek yang berasal dari 5 orang validator. Skala nilai untuk setiap aspek 1 sampai dengan 4, dengan kriteria seperti yang terdapat pada Tabel 1

Tabel 1. Kriteria Penilaian Validator

\begin{tabular}{|c|c|l|}
\hline Rata-Rata Nilai & Klasifikasi & \multicolumn{1}{c|}{ Kesimpulan } \\
\hline $0,00<\mathrm{Va} \leq 2,00$ & Tidak Baik & $\begin{array}{l}\text { Perangkat masih memerlukan konsultasi } \\
\text { intensif }\end{array}$ \\
\hline $2,00<\mathrm{Va} \leq 3,00$ & $\begin{array}{c}\text { Kurang } \\
\text { Baik }\end{array}$ & $\begin{array}{l}\text { Perangkat dapat digunakan dengan banyak } \\
\text { revisi }\end{array}$ \\
\hline $3,00<\mathrm{Va} \leq 3,50$ & Baik & $\begin{array}{l}\text { Perangkat dapat digunakan dengan sedikit } \\
\text { revisi }\end{array}$ \\
\hline $3,50<\mathrm{Va} \leq 4,00$ & Sangat Baik & Perangkat dapat digunakan tanpa revisi \\
\hline
\end{tabular}

\section{b. Analisis Data Hasil Uji Coba}

1) Analisis Instrumen angket Kemandirian Belajar Mahasiswa

Instrumen angket kemandirian belajar dalam penelitian ini adalah angket yang diberikan dengan materi menyelesaikan masalah kapita selekta matematika sekolah dasar. Butir pertanyaan disesuaikan dengan indikator yang digunakan untuk mengukur seberapa besar kemandirian belajar mahasiswa dilakukan uji coba terlebih dahulu di kelas uji coba instrumen yang berguna untuk mengetahui validitas dan reliabilitasnya.

2) Analisis Efektivitas Pembelajaran

Uji ketuntasan hasil belajar digunakan untuk mengetahui ketercapaian kemampuan mahasiswa pada materi kapita selekta matematika sekolah dasar. Untuk melihat tuntas tidaknya hasil belajar mahasiswa secara klasikal sebagai salah satu kriteria efektivitas pembelajaran, akan diuji hipotesis dengan uji rata-rata satu pihak.

Rumus uji statistik menggunakan : $\quad t=\frac{\bar{x}-\mu_{\mathrm{O}}}{\frac{s}{\sqrt{n}}} \quad$ (Sudjana, 2005: 227)

Sedangkan untuk melihat ketuntasan individual akan dilakukan diuji proporsi satu pihak dengan menggunakan rumus : 


$$
z=\frac{\frac{x}{n}-\pi_{o}}{\sqrt{\frac{\pi_{o}\left(1-\pi_{o}\right)}{n}}} \quad(\text { Sudjana, 2005: 233) }
$$

\section{HASIL DAN PEMBAHASAN}

Pada bagian ini akan diuraikan hasil penelitian pada setiap tahap pengembangan perangkat pembelajaran matematika model PBI khususnya pada materi kapita selekta matematika sekolah dasar. Model pengembangan perangkat pembelajaran yang digunakan adalah mengacu pada model pengembangan pendidikan umum yang dikemukakan oleh Plomp (dalam Rochmad, 2009:55). Tahapan pengembangan yang digunakan dalam penelitian ini adalah (1) investigasi awal (Preliminary Investigation); (2) perancangan (Design); (3) realisasi/konstruksi (Realization/ Construction); dan (4) pengujian, evaluasi, dan revisi (Test, Evaluation, and Revision).

Kriteria yang digunakan dalam menilai perangkat pembelajaran yang telah dihasilkan berdasarkan kriteria Nieveen (1999). Kriteria tersebut menilai kualitas perangkat pembelajaran berdasarkan tiga aspek, yaitu: validitas, kepraktisan, dan keefektifan. Perangkat pembelajaran yang dikembangkan dalam penelitian ini telah memenuhi aspek validitas isi karena isinya sesuai dengan prinsip-prinsip dan karakteristik model pembelajaran PBI. Hasil penilaian secara umum oleh validator terhadap perangkat pembelajaran yang dikembangkan disajikan dalam Tabel 2

Tabel 2. Rekapitulasi Hasil Validasi Perangkat Pembelajaran

\begin{tabular}{|c|l|c|c|c|c|c|c|c|}
\hline \multirow{2}{*}{ No. } & \multirow{2}{*}{ Perangkat } & \multicolumn{5}{|c|}{ Validator } & \multirow{2}{*}{$\begin{array}{c}\text { Rata- } \\
\text { rata }\end{array}$} & Klasifikasi \\
\cline { 3 - 8 } & & I & II & III & IV & V & \\
\hline 1. & Silabus & 3,70 & 3,60 & 3,80 & 3,70 & 3,20 & $\mathbf{3 , 6 0}$ & Sangat baik \\
\hline 2. & SAP & 3,56 & 3,42 & 3,50 & 3,50 & 3,25 & $\mathbf{3 , 4 5}$ & Baik \\
\hline 3. & $\begin{array}{l}\text { Modul } \\
\text { Pemb. }\end{array}$ & 3,64 & 3,13 & 3,57 & 3,29 & 3,07 & $\mathbf{3 , 3 4}$ & Baik \\
\hline 4. & Worksheet & 3,75 & 3,18 & 3,75 & 3,67 & 4,00 & $\mathbf{3 , 6 7}$ & Sangat baik \\
\hline
\end{tabular}

Berdasarkan Tabel 2 hasil validasi ahli terhadap perangkat pembelajaran menunjukkan bahwa perangkat yang dikembangkan mempunyai rata-rata pada interval 3,0-3,8 dengan klasifikasi baik dan sangat baik sesuai dengan kriteria yang telah ditetapkan di bab 3 . Sehingga dapat disimpulkan bahwa nilai validitas konstruks perangkat pembelajaran pada 
materi kapita selekta matematika sekolah dasar sesuai dengan model PBI memenuhi kreteria valid.

Angket kemandirian belajar mahasiswa, berdasarkan pada indikator yang termuat pada kisi - kisi instrumen terdapat enam indikator kemandirian belajar mahasiswa yaitu: (1) ketidaktergantungan terhadap oranglain, (2) memiliki kepercayaan diri, (3) berperilaku disiplin, (4) memiliki rasa tanggungjawab, (5) berperilaku berdasarkan inisiatif sendiri, (6) melakukan kontrol diri.

\section{$\underline{\text { Keefektivan }}$}

Instrumen yang digunakan dalam menguji keefektivan perangkat pembelajaran adalah, (1) lembar pengamatan keaktifan mahasiswa dan (2) tes kemandirian belajar. Hasil pengamatan keaktifan mahasiswa dan hasil tes kemandirian belajar mahasiswa yang diperoleh dianalisis dan digunakan untuk menentukan keefektifan perangkat pembelajaran yang dikembangkan. Berdasarkan hasil analisis diperoleh bahwa keaktifan mahasiswa termasuk kategori aktif.

\section{Kepraktisan}

Kepraktisan perangkat pembelajaran yang dikembangkan didasarkan pada keterlaksanaan perangkat pembelajaran di kelas. Nilai kepraktisan perangkat pembelajaran diperoleh berdasarkan hasil uji coba lapangan. Dari uji coba lapangan diperoleh hasil pengamatan terhadap proses pembelajaran, angket respon pengajar terhadap perangkat pembelajaran, dan angket respon mahasiswa terhadap perangkat pembelajaran setelah mengikuti pembelajaran.

Kemampuan pengajar mengelola pembelajaran, berdasarkan hasil pengamatan diperoleh rata-rata total skor 26,88 dari skor total 36 , berarti pembelajaran telah dilaksanakan dengan baik, respon mahasiswa tergolong positif, respon mahasiswa yang di ukur adalah perasaan mahasiswa terhadap komponen mengajar, pendapat mahasiswa terhadap komponen mengajar, minat mahasiswa, komentar mahasiswa terhadap keterbacaan, dan komentar mahasiswa terhadap media, lebih dari 50\% mahasiswa memberi tanggapan positif.

Hasil penelitian ini membuktikan bahwa penerapan model pembelajaran Problem Based Instruction (PBI) dapat meningkatkan kemandirian belajar mahasiswa pada mata kuliah Kapita Selekta Matematika Sekolah Dasar, terbukti dengan adanya peningkatan kemandirian belajar mahasiswa. Namun demikian masih terdapat aspek kemandirian yang perlu ditingkatkan diantaranya aspek manajemen diri, kesadaran belajar dan kemampuan 
pemecahan masalah. Belajar mandiri bukan berarti belajar sendiri, belajar mandiri dapat dilakukan bersama-sama dalam kelompok belajar ataupun dengan dosen. Belajar mandiri adalah belajar atas inisiatif sendiri dalam mengidentifikasi kebutuhan belajar, merumuskan tujuan belajar, mengidentifikasi sumber belajar, memilih dan menetapkan strategi belajar, serta mengevaluasi hasil belajar.

Program belajar mandiri dapat dilaksanakan secara efisien dan efektif jika setiap pembelajar dapat menyusun jadwal kegiatan belajar harian serta melaksanakannya secara teratur dan disiplin. Dengan memiliki jadwal harian, pembelajar akan dapat merencanakan kapan bagian demi bagian dari suatu mata kuliah harus selesai dipelajari, sehingga dapat disesuaikan dengan jadwal bimbingan belajar dan ujian. Perencanaan ini dapat juga dilakukan dalam satu paket mata kuliah, yang terdiri dari beberapa bagian, ditambah dengan media pendukung lainnya.

\section{SIMPULAN DAN SARAN}

Secara umum dapat disimpulkan bahwa Perangkat pembelajaran matematika yang dikembangkan dengan model problem based instruction (PBI) adalah valid, praktis, dan efektif untuk meningkatkan kemandirian belajar mahasiswa.

Sebagai saran dalam penelitian ini adalah (1) pembelajaran matematika dengan model problem based instruction ( $\mathrm{PBI}$ ) perlu diterapkan pada materi lainnya sehingga penerapan pembelajaran ini menjadi lebih luas, (2) perlu dikembangkan lagi variasi pembelajaran dengan menggunakan model problem based instruction (PBI), hal ini akan dapat meningkatkan kemandirian belajar mahasiswa, (3) dalam penerapan pembelajaran menggunakan model problem based instruction (PBI) perlu adanya pengawasan terhadap mahasiswa, sehingga pembelajaran dapat berjalan secara efektif dan efisien.

\section{DAFTAR PUSTAKA}

Hake, R.R. (1998). "Interactive - Engagement Versus Traditional Methods ; A. Six Thousand - Student Survey of Mechanics Tes Data for Introductory Physics Course". American Association of Physic Teacher. Vol 66 (1), hal: 64-74.

Kennedy, N.S. (2009). "Toward a Dialogical Pedagogy: Some Characteristic of Community of Mathematics Inquiry". Eurasia Journal of Mathematics, Science \& Tecnology Education. Vol 5 (1), hal: $71-78$.

Rochmad, (2009). Pengembangan Model Pembelajaran Matematika Beracuan Konstruktivisme yang Melibatkan Penggunaan Pola Pikir Induktif-Deduktif (Model PMBK-ID) untuk Siswa SMP/MTs. Desertasi, Universitas Negeri Surabaya. 


\section{FIBONACCI $\quad$ Jurnal Pendidikan Matematika \& Matematika}

Rosita, Ida. (2013). Upaya Penerapan Metode Problem Based Instruction untuk Meningkatkan Hasil Belajar Siswa. Skripsi, Universitas Pendidikan Indonesia.

Siahaan, Sudirman. (2003). "E-Learning (Pembelajaran Elektronik) Sebagai Salah Satu Alternetif Kegiatan Pembelajaran”. Jurnal Pendidikan dan Kebudayaan. No.042-Mei 2003. Jakarta: Depdiknas

Sudjana. (2005). Metode Statistika. Bandung: Tarsito.

Trianto. (2009). Mendesain Model Pembelajaran Inovatif-Progresif, Konsep, Landasan.dan Implementasinya pada Kurikulum Tingkat satuan pendidikan (KTSP). Jakarta: Kencana Prenada Media Grop. 